DOI: $10.4274 /$ tpa.45.348

\title{
Kritik çocuk hastalarda akut transfüzyon reaksiyonları
}

\section{Acute transfusion reactions in critically ill children}

\author{
Demet Demirkol, Metin Karaböcüoğlu, Fatih Mehmet Keleşoğlu*, Nurhan Özata**, Agop Çıtak** \\ İstanbul Üniversitesi İstanbul Tıp Fakültesi, Çocuk Sağlığı ve Hastalıkları Anabilim Dalı, Yoğun Bakım Bilim Dalı, Istanbul, Türkiye \\ *istanbul Üniversitesi İstanbul Tıp Fakültesi, Çocuk Sağlığı Enstitüsü, İstanbul, Türkiye \\ **istanbul Üniversitesi İstanbul Tıp Fakültesi, Çocuk Sağlığı ve Hastalıkları Anabilim Dalı, İstanbul, Türkiye
}

\section{Özet}

Amaç: Bu çalışmanın amacı, kritik çocuk hastalarda akut transfüzyon reaksiyonlarının sıklığını ve tipini belirlemektir.

Gereç ve Yöntem: Çalışmaya 2006 ve 2007 Şubat ayları arasında Yoğun Bakım Birimi'nde yatan hastalar ileriye dönük olarak alındı. Transfüzyon yapılan her hastada, yaşamsal bulgular transfüzyon öncesinde, sırasında ve sonrasındaki dördüncü saatte hasta başı hemşiresi tarafından kaydedildi.

Bulgular: Çalışma döneminde 219 hastaya 762 transfüzyon yapıldı. Kritik hasta çocukların \%17,8'inde ( $\mathrm{n}=38$ ) akut transfüzyon reaksiyonu gelişti. Akut transfüzyon reaksiyon sıklığı \%4,9 (38/762) bulundu. Akut transfüzyon reaksiyonlarının tamamı hemolitik olmayan ateş reaksiyonlarından oluşmaktaydı. Bu reaksiyonların \%68'i $(n=26)$ eritrosit süspansiyonu, \%21'i $(n=8)$ trombosit süspansiyonu, \%11'i ( $n=4)$ damardan verilen immünglobulin ile ilişkiliydi. Kan ve kan ürünü transfüzyonları kendi içlerinde değerlendirildiğinde hemolitik olmayan ateş reaksiyonun sırasıyla trombosit süspansiyonu transfüzyonlarının \% $\%$ 'inde $(n=8)$, eritrosit süspansiyonu transfüzyonlarının \%6,1'inde $(n=26)$ ve damardan immünglobulin enfüzyonlarının \%3,7'sinde $(n=4)$ geliştiği belirlendi. Hastaların \%52'sinde ( $n=116)$ transfüzyon tekrarlandı. Tekrarlanan transfüzyonları olan hastalarda akut transfüzyon reaksiyon sıklığı \%9 $(n=11)$ bulundu. Tekrarlanan transfüzyonlar ile akut transfüzyon reaksiyon gelişim riski arasında istatiksel olarak anlamlı ilişki saptandı $(p=0,006)$.

Çıkarımlar: : Kritik hasta çocuklarda hemolitik olmayan ateşli transfüzyon reaksiyonu sıktır. Tekrarlanan transfüzyonlar akut transfüzyon reaksiyonu gelişme olasıığını artırmaktadır. Transfüzyon yapılan hastaların gözetimlerinin yapılması transfüzyon reaksiyonlarının sıklığının, tipinin, risk etmenlerinin belirlenmesi ve güvenlik önlemlerinin artırılması açısından önemlidir. (Türk Ped Arş 2010; 45: 348-52)

Anahtar sözcükler: Akut transfüzyon reaksiyonu, çocuk yoğun bakım, hemolitik olmayan ateşli reaksiyon, kritik hasta çocuk

\section{Summary}

Aim: This study was undertaken to determine the incidence and type of acute transfusion reactions in a pediatric intensive care unit.

Material and Method: The patients admitted to our pediatric intensive care unit between February 2006 and February 2007 were prospectively recorded. A bedside nurse recorded the patients' vital signs before, during and up to 4 hours after the transfusions.

Results: A total of 762 transfusions were administered to 219 patients during the study period. Acute transfusion reactions were diagnosed in $17.8 \%(n=38)$ of transfusions in critically ill children. Acute transfusion reactions incidence rate was found as $4.9 \%(38 / 762)$. All the acute transfusion reactions were febrile non hemolytic reactions. Febrile non hemolytic reactions were associated $68 \%(n=26)$ with red blood cell transfusions, $21 \%(n=8)$ with platelet transfusions and $3.7 \%(n=4)$ with intravenous immunoglobulin transfusions. Overall $8 \%(n=8)$ of platelet, $6.1 \%(n=26)$ of red blood cell and 3.7\% $(n=4)$ of immunoglobulin infusions were involved in febrile non hemolytic reactions. Transfusions were repeated in $52 \%(n=116)$ of patients. Acute transfusion reactions incidence rate was found $9 \%(n=11)$ in multiple transfusions. There was significant association between acute transfusion reactions and multiple transfusions $(p=0.006)$.

Conclusions: Febrile non hemolytic reactions occur frequently in critically ill pediatric patients who require transfusions. The acute transfusion reaction risk increases with multiple transfusons. The surveillance of transfusions given to pediatric intensive care patients enhances the knowledge about the incidence, type, risk factors and the safety standard required for transfusions. (Turk Arch Ped 2010; 45: 348-52)

Key words: Acute transfusion reaction, critically ill child, febrile non hemolytic reaction, pediatric intensive care unit

Yazışma Adresi/Address for Correspondence: Dr. Demet Demirkol, İstanbul Üniversitesi İstanbul Tıp Fakültesi, Çocuk Sağlı̆̆ı ve Hastalıkları Anabilim Dalı, Yoğun Bakım Bilim Dalı, İstanbul, Türkiye E-mail: d_demirkol@hotmail.com Geliş Tarihi/Received: 15.02.2010 Tarihi/Accepted: 01.06.2010 


\section{Giriş}

Kritik hastalar yaş, yoğun bakıma yatış gerektiren hastalıkları, altta yatan hastalıkları, fizyolojik kompansatuvar mekanizmalarının yeterliliği konularında büyük değişkenlik gösterirler. Ancak tüm kritik hastalar oksijen taşıma kapasitesi ve doku perfüzyonunun ideal hale getirilmesine gereksinim duyarlar. Devam eden kan kayıpları, girişimsel monitorizasyon uygulamaları, yinelenen laboratuvar testleri, yetersiz kemik iliğsi işlevi ve artmış eritrosit yıkımı ile birleşince kan transfüzyonunu zorunlu hale getirir. Ek olarak yoğun bakım hastalarının çoğunda plazma, trombosit konsantresi verilmesini gerektiren pintılaşma bozuklukları vardır. Yoğun bakımda yatan kritik hastalar kan ve kan ürünlerinin çoğunu kullanıllar. Bölgesel kan merkezlerindeki kanların yaklaşık \%8'nin kritik hastalar tarafından kullanıldığı düşünülmektedir (1). Yoğun bakıma yatıııan kritik çocuk hastaların \%50'sinde yatışları sırasında eritrosit transfüzyonu yapilır (2).

Kan ve kan ürünleri güçlü tedavi etkileri yanında ciddi yan etkilerinin de olabilmesi nedeniyle ilaç olarak değerlendirilmelidirler. İlaçlardan farklı olarak kan ürünlerinin gerekçeleri ve güvenilirlikleri konusunda yeterli veri yoktur. Kan ürünü transfüzyonu ilişkili reaksiyonlar hayatı tehdit edebilir (3-5). Transfüzyona bağlı reaksiyonlar uygulamadan hemen sonra veya günler içinde gelişebilir. Akut transfüzyon reaksiyonları (ATR) uygulamadan sonraki ilk 24 saat içinde sıklıkla ilk dört saat içinde gelişen reaksiyonları tanımlamakta kullanılır $(6,7)$. Akut transfüzyon reaksiyonları kullanılan kan ve kan ürünü, uygulanan hasta grubu ve yaşla bağlantılı olarak değişebilmektedir $(4,5,7)$. Çocuklarda ATR sıklığı ve tipleri ile ilgili yeterli veri yoktur. Çalışmamızın amacı kritik hasta çocuklarda ATR'lerin sıkıı̆ını ve türünü araştırmaktır.

\section{Gereç ve Yöntem}

Çalışmamız, İstanbul Tıp Fakültesi Çocuk Yoğun Bakım Birim'inde (ÇYBB) yapıldı. Şubat 2006 ve Şubat 2007 tarihleri arasında yoğun bakıma yatıılan 1 ay-18 yaş arasında, en az bir kez transfüzyon yapılan hastalar çalışmaya alındı.

Transfüzyon, hacime bakılmaksızın herhangi bir kan bileşeninin yerine konması olarak tanımlandı. Eritrosit, granülosit ve trombosit süspansiyonları, taze donmuş plazma (TDP), albümin ve intravenöz immünglobulin (IViG) uygulanan hastalar ATR açısından riskli grup olarak kabul edildi. Faktör konsantresi alan hastalar çalışmaya dahil edilmedi.
Akut transfüzyon reaksiyonu transfüzyon sırasında veya sonrasındaki dört saatte gelişen reaksiyonlar olarak tanımlandı. Akut transfüzyon reaksiyonları hemolitik reaksiyon, hemolitik olmayan ateş reaksiyonu (HOAR), hafif ve ağır alerjik reaksiyon, bakteriyel bulaşma, transfüzyon ilişkili akciğer hasarı, transfüzyon ilişkili sıvı yükü, izole hipotansiyon olarak gruplandı (Tablo 1). Transfüzyon sırasında veya sonrasında dört saat süresince ateş (vücut ısısında $\geq 1^{\circ} \mathrm{C}$ 'lik artış veya vücut ısısının $\geq 38,5^{\circ} \mathrm{C}$ olması), üşüme, dispne ve/veya hipoksemi (oksijen doygunluğunda iki dakikadan uzun süre dakikada $\% 5$ azalma), döküntü ve/veya kaşıntı, ağrı (lomber, torasik ve baş), anksiyete ve/veya ajitasyon, hipotansiyon (sistolik veya diyastolik arteryel basınçta en az 20 mm Hg'lık düşme), hipertansiyon (sistolik veya diyastolik arteryel basınçta en az 20 mmHg'lık artış), kırmızı idrar bulgularından herhangi birinin varlığı kaydedildi.

Transfüzyon yapılan her hastada hazırlanmış olan form hasta başı hemşiresi tarafından doldurdu. Eksik formu olan hastalar çalışma dışı bırakıldı. Çalışma formuna transfüze edilen kan ve kan ürünlerinin tipi, transfüze edilen kan ürününün seri numarası, transfüzyonun başlangıç ve sonlandırıma zamanı, transfüzyon öncesinde, sırasında ve sonrasında dört saat süresince oksijen doygunluğu, solunum ve kalp hızı, kan basıncı ve vücut ısısı kaydedildi.

Akut transfüzyon reaksiyonları tanısı, hasta başı hemşiresi tarafından kaydedilen formlar, hasta dosyaları ve laboratuvar verileri tek bir öğretim üyesi tarafından bağımsız şekilde değerlendirilerek kondu.

\section{İstatistik}

Tüm istatistik analizleri Statistical Package for Social Sciences (SPSS 16; SPSS Inc, Chicago, IL) programı kullanılarak yapıldı. Kategorisel sonuçlar yüzde olarak ifade edildiler. Bağımlı gruplarda kategorisel sonuçların değerlendirilmesinde McNemar testi kullanıldı. İstatistiksel anlamlılık $p<0,05$ olarak tanımlandı.

\section{Bulgular}

Çalışma süresince toplam 219 hastaya 762 transfüzyon yapıldı. Transfüze edilen kan ve kan ürünleri sırasıyla, $\% 56$ $(\mathrm{n}=426)$ eritrosit süspansiyonu, $\% 19,3(\mathrm{n}=147)$ TDP, $\% 13$ $(n=100)$ trombosit süspansiyonu, \%10,5 $(n=80)$ IVIG, \%1 albümin $(n=8)$ ve $\% 0,2(n=1)$ granülosit süspansiyonu idi.

Hastaların \%17,8'inde $(n=38)$ ATR gelişti. Akut transfüzyon reaksiyonlarının sıklığı \%4,9 (38/762) bulundu. Akut transfüzyon reaksiyonlarının tamamı HOAR idi. Diğer ATR reaksiyonları olan hafif ve ağır alerjik reaksiyon, 
bakteriyel bulaşma, izole hipotansiyon, transfüzyon ilişkili akciğer hasarı ve hemolitik reaksiyon gözlenmedi. Hemolitik olmayan ateş reaksiyonlarının \%68'i (26/38) eritrosit süspansiyonu, \%21'i (8/38) trombosit süspansiyonu, \%10,5'i (4/38) IViG enfüzyonu ile bağlantılı gelişti (Tablo 2).

Hastaların \%52'sinde $(n=116)$ tekrarlanan transfüzyon gereksinimi oldu. Tekralanan transfüzyon yapılan hastalarda ATR sıklı̆ı̆ \%9 bulundu (11/116). Tekrarlanan transfüzyon yapılan hastalarda ATR'lerin \%63'ü (7/11) eritrosit süspansiyonu, \%27'si (3/11) trombosit süspansiyonu ve \%10'u (1/11) IVIG transfüzyonu ile ilişkiliydi. Tekrarlanan transfüzyon ile ATR gelişim riski arasında anlamlı ilişki saptandı $(p=0,006)$.

Kan ve kan ürünü transfüzyonları kendi içlerinde değerlendirildiğinde HOFR'nin sırasıyla trombosit süspansiyonu transfüzyonlarının $\% 8$ 'inde $(n=8)$, eritrosit süspansiyonu transfüzyonlarının \%6,1'inde $(n=26)$, ve IVIG enfüzyonlarının \%3,7'sinde $(n=4)$ geliştiği belirlendi. Taze donmuş plazma, albümin ve granülosit süspansiyonu transfüzyonları ilişkili ATR saptanmadı.

\section{Tablo 1. ATR tanımları ve tanı ölçütleri}

\begin{tabular}{|c|c|}
\hline \multicolumn{2}{|l|}{ Hemolitik reaksiyon } \\
\hline Tanım & Eritrositlerin, alıcı ve verici arasında immün veya immün olmayan mekanizmalara bağlı parçalanması \\
\hline Klinik bulgular & Ateş, titreme, başağrısı, bulantı, ağrı, hipotansiyon \\
\hline Laboratuvar verileri & Hemoglobinüri, hemoglobinemi \\
\hline \multicolumn{2}{|c|}{ Ateşli hemolitik olmayan reaksiyon } \\
\hline Tanım & $\begin{array}{l}\text { Alıcı antikorlarının verici lökositlerine bağlanması ve/veya biyolojik yanıt düzenleyicilerinin } \\
\text { (kompleman, lipidler, sitokinler) transfüze edilen kan ürününde birikmesi sonucu altta yatan } \\
\text { hastalıktan bağımsız ve ATR başka tipi ile açıklanamayan ateş gelişmesi }\end{array}$ \\
\hline Klinik bulgular & Ateş, titreme, baş ağıısı, bulantı, taşikardi \\
\hline \multicolumn{2}{|c|}{ Hafif alerjik reaksiyon } \\
\hline Tanım & Tip I aşırı duyarllık reaksiyonunun neden olduğu deri reaksiyonları \\
\hline Klinik bulgular & Döküntü ve kaşıntı \\
\hline \multicolumn{2}{|c|}{ Ağır alerjik reaksiyon } \\
\hline Tanım & Tip I aşıı duyarllık reaksiyonunun neden olduğu sistemik reaksiyon \\
\hline Klinik bulgular & Dispne, stridor, hışıttı, hipotansiyon, bulantı, kusma, diyare, kızarıklık, anjiyoödem, şok \\
\hline \multicolumn{2}{|l|}{ Bakteriyel bulaş } \\
\hline Tanım & $\begin{array}{l}\text { Kan ürünün, vericideki enfeksiyon, flebotomi sırasında veya üretim sırasında bulaş } \\
\text { olması ve alıııda enfeksiyon gelişmesi }\end{array}$ \\
\hline Klinik bulgular & Ateş, titreme, dispne, taşikardi, hipotansiyon, şok \\
\hline Laboratuvar verileri & Pozitif kan kültürü \\
\hline \multicolumn{2}{|c|}{ Transfüzyon ilişkili akciğer hasarı } \\
\hline Tanım & $\begin{array}{l}\text { Plazma içeren herhangi bir kan ürününün transfüzyonu sonrasında verici (antikor varlığı şart) } \\
\text { ile alıcı (nötrofiller) arasında reaksiyon sonucu akut akciğer hasarı gelişmesi }\end{array}$ \\
\hline Klinik bulgular & Dispne, hipoksi, hipotansiyon, taşikardi, ateş \\
\hline Laboratuvar verileri & Akciğer grafisinde pulmoner ödem \\
\hline \multicolumn{2}{|c|}{ Transfüzyon ilişkili sıvı yükü } \\
\hline Tanım & Sıvı yüküne bağlı konjestif kalp yetersizliği ve akciğer ödem gelişmesi \\
\hline Klinik bulgular & Dispne, hipoksemi, baş ağrısı, hipertansiyon, yüksek santral venöz basınç \\
\hline Laboratuvar verileri & Akciğer grafisinde pulmoner ödem varlığı \\
\hline \multicolumn{2}{|l|}{ İzole hipotansiyon } \\
\hline Tanım & $\begin{array}{l}\text { Belirli durumlarda bradikinin üretilmesine bağlı (negatif yüklü filtreler, anjiyotensin çevirici enzim } \\
\text { inhibitörü kullanımı veya anormal bradikinin metabolizması) izole hipotansiyon gelişmesi }\end{array}$ \\
\hline Klinik bulgular & Ani hipotansiyon, yüzde kızarma \\
\hline
\end{tabular}

* Tanı ölçütü: Transfüzyon sırasında veya sonrasındaki dört saatte klinik bulgulardan bir veya daha fazlasının varlığı ve/veya laboratuvar testlerinin pozitif olması 


\section{Tartışma}

Akut transfüzyon reaksiyonları sıklığı ile ilgili çalışmalar genelde erişkin hastalarda yapılmıştır ve ATR'nin kan ürünü transfüzyonlarının \%0,2-10'unda geliştiği bildirilmektir $(8,9)$. Çocuk yaş grubunda ATR sıklığını ve tipini araştıran çalışma sayısı çok daha azdır. Kanada'nın Quebec eyaleti hemovijilans sistemi (QHS) verilerine göre tüm transfüzyonlarda ATR sıklı̆ı $\% 0,35$, bir yaşından küçük çocuklarda $\% 1,1,1-17$ yaş arası grupta \%8,4 bulunmuştur (10). Ingiltere'de 1996-2205 yılları arasındaki transfüzyon kayıtları incelendiğinde transfüzyon reaskisyonlarının \%10'nun 18 yaş altındaki çocuklarda geliştiği ve ATR sıklığının \%9,3 (30/321) olduğu gösterilmiştir (5).

Çocuk yoğun bakım hastalarında ATR sıklığının ve tipinin araştıııdığı tek çalışma vardır. Gauvin ve ark.'larının (7) 2509 transfüzyonu içeren çalışmasında kritik çocuk hastaların \%10,8'de ATR gelişmiştir ve ATR sıklığının 100 transfüzyonda 1,6 olduğu bulunmuştur. Çalışmamızda ATR sıklığı \%17,8 ve ATR sıklığı 100 transfüzyonda 4,9 olarak saptandı. Çalışmamızdaki ATR sıklığı Gauvin ve ark.'larının (7) çalışmasından ve kritik olmayan çocuk hastalarda yapılan diğer çalışmalardan yüksektir. Çalışmamıza, Gauvin ve ark.' 'larının (7) çalışmasından farklı olarak albümin ve IVIG uygulanan hastalar alındı. Ancak albümin ve IVIG uygulanan hastalardan yalnızca IVIG uygulanan dört hastada ATR gelişti, bu ATR sıklığımızın yüksek olmasını açıklamakta yetersiz kaldı. Kritik hasta çocuklarda ATR sıklığını araştıran tek bir çalışma olduğundan gerçek sıklığı belirlemede bundan sonraki çalışmaların yol gösterici olacağını düşünmekteyiz.

Alman hemovijilans sisteminin 1997-2007 yılları arasındaki kayıtları incelendiğinde transfüzyon yan etkilerinden \%58'nin ATR olduğu, bunların \%76'sının minör reaksiyonlar, \%13'nün HOAR olduğu bulunmuştur (3). Gauvin ve ark.'larının (7) çalışmasında kritik hasta çocuklarda en sık ATR'nın HOAR olduğu (96:10 000 transfüzyon

\begin{tabular}{|l|c|c|}
\hline \multicolumn{3}{|c|}{ Tablo 2. Transfüzyonların özellikleri } \\
\hline $\begin{array}{l}\text { Kan ve kan } \\
\text { ürünü tipi }\end{array}$ & $\begin{array}{c}\text { Tüm transfüzyonlar } \\
(\mathbf{n = 7 6 2 )}\end{array}$ & $\begin{array}{c}\text { ATR gelişen } \\
\text { transfüzyonlar }(\mathbf{n}=\mathbf{3 8})\end{array}$ \\
\hline Eritrosit & $426(56)$ & $26(68,5)$ \\
\hline Taze donmuş plazma & $147(19,2)$ & $0(0)$ \\
\hline Trombosit & $100(13,1)$ & $8(21)$ \\
\hline Intravenöz immünglobulin & $80(10,6)$ & $4(10,5)$ \\
\hline Albümin & $8(1)$ & $0(0)$ \\
\hline Granülosit & $1(0,1)$ & $0(0)$ \\
\hline
\end{tabular}

ATR: Akut transfüzyon reaksiyonları ünitesi) ikinci sıklıkta hafif alerjik reaksiyon geliştiği (24:10 000 transfüzyon ünitesi) gösterilmiştir. Kritik hasta çocuklarda HOAR sıklığının genel toplumdan fazla olduğu dikkat çekmektedir. Çalışmamızda yalnızca HOAR saptandı, diğer ATR tipleri görülmedi.

Hemolitik olmayan ateş reaksiyonlarının, lökosit-reaktif antikorları olan hastada transfüze edilen verici lökositlerinden pirojenik sitokinler ve hücre içi maddelerin salınması ile gerçekleştiği düşünülmektedir (10). Oda ısısında bulaşlı lökositlerin yaşam süresi uzadığından trombosit transfüzyonundan sonra HOAR olasılığı diğer kan ve kan ürünü transfüzyonlarından yüksektir. Hemolitik olmayan ateş reaksiyonları aferez yöntemi ile hazırlanan ertirosit transfüzyonlarının \%1,1'inde, trombosit transfüzyonlarının \%1,7'sinde gelişmektedir (11). Gauvin ve ark.'larının (7) çalışmasında ATR'lerinin \%48'i eritrosit transfüzyonu ile bağlantılı gelişmiştir. Çalışmamızda da en sık eritrosit transfüzyonu uygulanmış ve ATR sıklıkla eritrosit transfüzyonu bağlantılı gelişmiştir. Transfüzyonlar kendi içinde değerlendirildiğinde ise trombosit transfüzyonu bağlantıı HOAR olasılığının eritrosit transfüzyonundan yüksek olduğu saptanmıştır. Çalışmamız, kritik hasta çocuklarda HOAR'ın trombosit transfüzyonlarından sonra diğer kan ve kan ürünü transfüzyonlarına göre sık geliştiğini gösteren ilk araştırmadır.

Çalışmamızda saptadığımız önemli diğer sonuç tekrarlanan transfüzyon ile ATR olasılığının artmasıdır. Kan ve kan ürünü ile temas sıklığı artıkça transfüzyon reaksiyon gelişme olasığının artması mantıklı gözükmektedir. Her ne kadar çalışmamı sırasında hayatı tehdit eden yan etki gelişmemişse de bu sonuçlar değerlendirildiğinde tekrarlanan transfüzyonların ciddi yan etki görülme olasılığını artırabileceği göz önünde bulundurulmalıdır.

Çalışmamız kritik çocuk hastalarda ATR'leri araştıran ikinci çalışma olması açısından değerlidir. Ülkemizde çocuk yoğun bakım hastalarında bölgesel transfüzyon yan etkilerini belirleyen ilk ileriye dönük çalışmadır.

Çalışmamızın bazı kısıtlamaları vardır. Öncelikle tek merkezde yapılmıştır ve olgu sayısı diğer ATR tiplerini belirlemekte yetersiz kalmış olabilir. Kritik hasta çocuklarda transfüzyon risklerini araştıran çok merkezli çalışmalara gereksinim vardır. İkinci olarak çalışmamızda ATR risk etmenleri araştııımamıştır. Son olarak transfüzyon sonrası gözlem dört saat ile sınırlandırımıştır ki bu bazı ATR'lerin göz ardı edilmesine yol açmış olabilir.

Sonuç olarak kritik hasta çocuklarda ATR olasılığı genel toplumdan fazladır. Tekrarlanan transfüzyonlar ATR olasılı̆ıını artırmaktadır. Bu sonuçlar kritik hasta çocuklarda 
kan ve kan ürünü transfüzyonunda kısıtlayıcı politkanın kullanılması açısından yol gösterici olabilir. Transfüzyon yapılan hastaların gözleminin yapılması transfüzyon reaksiyonlarının sıklığının, tipinin, risk etmenlerinin belirlenmesi ve güvenlik önlemlerinin artırıması açısından önemlidir.

\section{Kaynaklar}

1. Walsh TS. Is stored blood good enough for critically ill patients? Crit Care Med 2005; 33: 238-9.

2. Morris KP, Naqvi N, Davies P, Smith M, Lee PW. A new formula for blood transfusion volume in the critically ill. Arch Dis Child 2005; 90: 724-8.

3. Kleinman $\mathrm{SH}$, Chan $\mathrm{P}$, Robillard P. Risks associated with transmission of cellular blood components in Canada. Transf Med Rev 2003; 17: 120-62.

4. Stanislawski KB, Günay AL, Heiden M, Funk MB. The German Haemovigilance System-reports of serious adverse transfusion reactions between 1997 and 2007. Transf Med 2009; 19: 1-10.
5. Stainsby D, Jones H, Wells AW, Gibson B, Cohen H. Adverse outcomes of blood transfusions in children: analysis of UK reports to the serious hazards of transfusion scheme 1996-2005. Br J Haematol 2008; 141: 73-9.

6. Bercher ME. Noninfectious complications of blood transfusion. In: Bercher ME, eds. AABB tecnical manual. 14th ed. Bethesda: American Assocition of Blood Banks; 2002: 512-85.

7. Gauvin F, Lacroix J, Robillard P, Lapointe H, Hume H. Acute transfusion reactions in the pediatric intensive care unit. Transfusion 2006; 46: 1899-908.

8. Cliement-Peris $\mathrm{C}$, Velez-Rosario R. Immediate transfusion reactions. P R Health Sci J 2001; 20: 229-35.

9. Robillard P, Nawej KI, Jochem K. The Quebec hemovigilance system: description and results from the first two years. Transfus Apher Sci 2004; 31: 111-22.

10. Eder AF, Chambers LA. Noninfectious complications of blood transfusion. Arch Pathol Lab Med 2007; 131: 708-18.

11. Federowicz I, Barrett BB, Andersen J, Urashima M, Popovsky $\mathrm{MA}$, Anderson KC. Charecterization of reactions after transfusion of cellular blood components that are white cell reduced before storage. Transfusion 1996; 36: 21-8. 